\title{
Groundwater, flooding and superficial deposits in the Findhorn catchment
}

\author{
A.M. MacDonald ${ }^{1 *}$, A.G. Hughes ${ }^{2}$, C.A. Auton ${ }^{1}$, D.J. Lapworth ${ }^{3}$, M.M. Mansour ${ }^{2}$, \\ T. Vounaki ${ }^{2}$, A. Finlayson ${ }^{1}$ and M.T. Graham ${ }^{1}$
}

\author{
${ }^{1}$ British Geological Survey, West Mains Rd, Edinburgh, EH9 3LA; ${ }^{2}$ British Geological Survey, Keyworth, Nottingham NG12 5GG \\ ${ }^{3}$ British Geological Survey, Crowmarsh Gifford, Wallingford OX10 8BB \\ *Email: amm@bgs.ac.uk
}

\begin{abstract}
The Forres area in north-east Scotland was subjected to one of the most catastrophic floods in UK history when the River Findhorn flooded in 1829. In recent times, Forres has also flooded to a lesser extent (notably in 1997 and 2001) and a series of flood alleviation schemes have been designed to help protect the town. This has enabled a detailed examination of the role of groundwater within the floodplain. Detailed 3D geological characterisation and modelling, pumping tests, water-level monitoring and environmental tracers have been used to characterise groundwater flow within the superficial deposits. A detailed groundwater model has been developed using the ZOOM suite of models to further investigate groundwater/surface water interactions and groundwater flooding. The research has demonstrated that there is significant groundwater storage and flow within the thick and complex superficial deposits in the River Findhorn floodplain which is closely coupled to surface water. Consequently, the flood alleviation schemes have been modified to balance protection from surface water flooding and from groundwater flooding.
\end{abstract}

\section{Introduction}

The Forres area in NE Scotland was subjected to one of the most catastrophic floods in UK history when the River Findhorn flooded in 1829 (McEwen and Werritty, 2007). Since that time, the floodplain has been built on as the town of Forres has expanded. In recent times, Forres has also flooded (notably in 1997 and 2001) but to a much lesser extent. These recent floods were mainly a result of elevated flows in the Burn of Mosset, which flows through the centre of Forres, rather than from the River Findhorn (Choudhury and Patterson, 2006). A separate flood alleviation scheme has been designed for the Burn of Mosset, and the implications for groundwater are described in MacDonald et al. $(2006 ; 2011)$.

If a flood with a return period of 1-in-200 years was to occur in the River Findhorn, there would be significant damage to the town of Forres (Figure 1), therefore a flood alleviation scheme is proposed for west Forres and the Pilmuir area. This scheme involves a series of embankments and river channel engineering to stop the eastward movement of water through Forres, and a series of drains to accommodate storm water in the Pilmuir sub-catchment. A critical issue to the effectiveness of the flood alleviation scheme is the role of groundwater.

This paper describes the work undertaken by BGS to characterise the role of groundwater in flooding in the Findhorn floodplain near Forres. Detailed geological, hydrogeological and hydrogeochemical characterisation was undertaken to develop a conceptual model of groundwater flow and storage in this area. This was tested using a numerical groundwater model which could be used to forecast the potential impact of proposed flood alleviation schemes. Scheme designs were then modified to minimise groundwater flooding.

\section{Methods}

The floodplain was investigated using an interdisciplinary team during 2006-2008. The following methods were used:

1. The Quaternary (superficial) geology for the lower part of the River Findhorn catchment was remapped. Interpreted cross sections were produced for the area and a 3D geological model constructed.

2. The hydrogeology of the floodplain was characterised by constructing 27 piezometers, taking samples for particle size analysis and geological logging and carrying out pumping tests. The local of the piezometers are shown in Figure 2.

3. Several automatic water level recorders were installed in strategic piezometers.

4. Groundwater samples for chemical analysis, including residence time indicators, were taken from 27 sites.

5. Topsoil permeability was measured in 61 locations using a Guelph Permeameter.

6. The data acquired were then combined with existing information (such as rainfall and river stage data) to produce a conceptual model of groundwater flow in the floodplain and of the extent of groundwater flooding.

7. This conceptual model was tested and refined by numerical groundwater modelling using ZOOM. Prediction runs were undertaken to test the effect of the proposed flood alleviation scheme.

\section{Results}

The data collection and analysis has allowed us to understand the hydrogeology of the floodplain of the River Findhorn west 


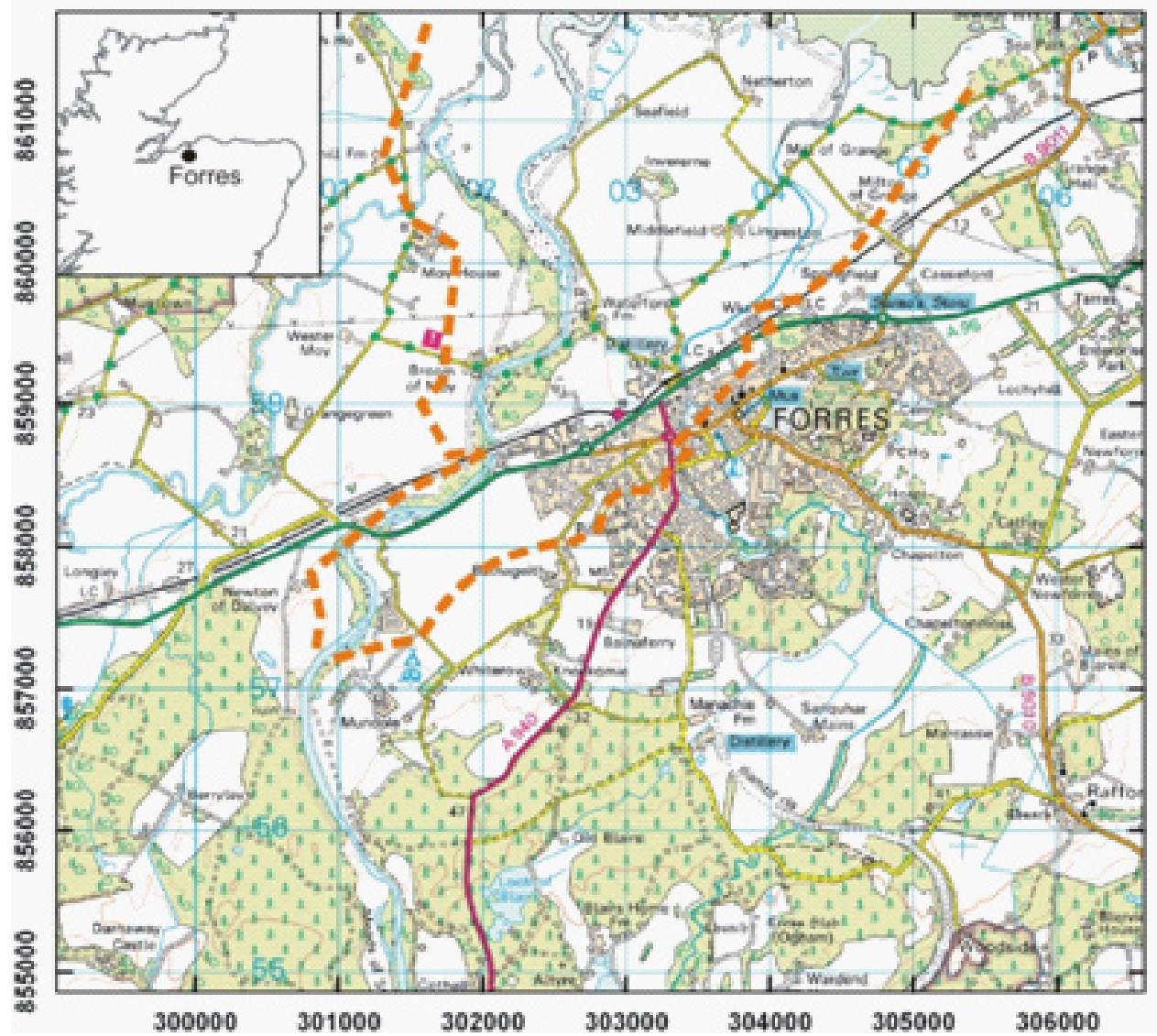

Figure 1 The location of Forres, Morayshire, showing the approximate modelled extent of flooding for a 1 in 200 year flood event. This extent matches closely the observed flooded area from 1829. Contains Ordnance Survey Data $\odot$ Crown Copyright and Database rights 2012. Licence No. 100021290

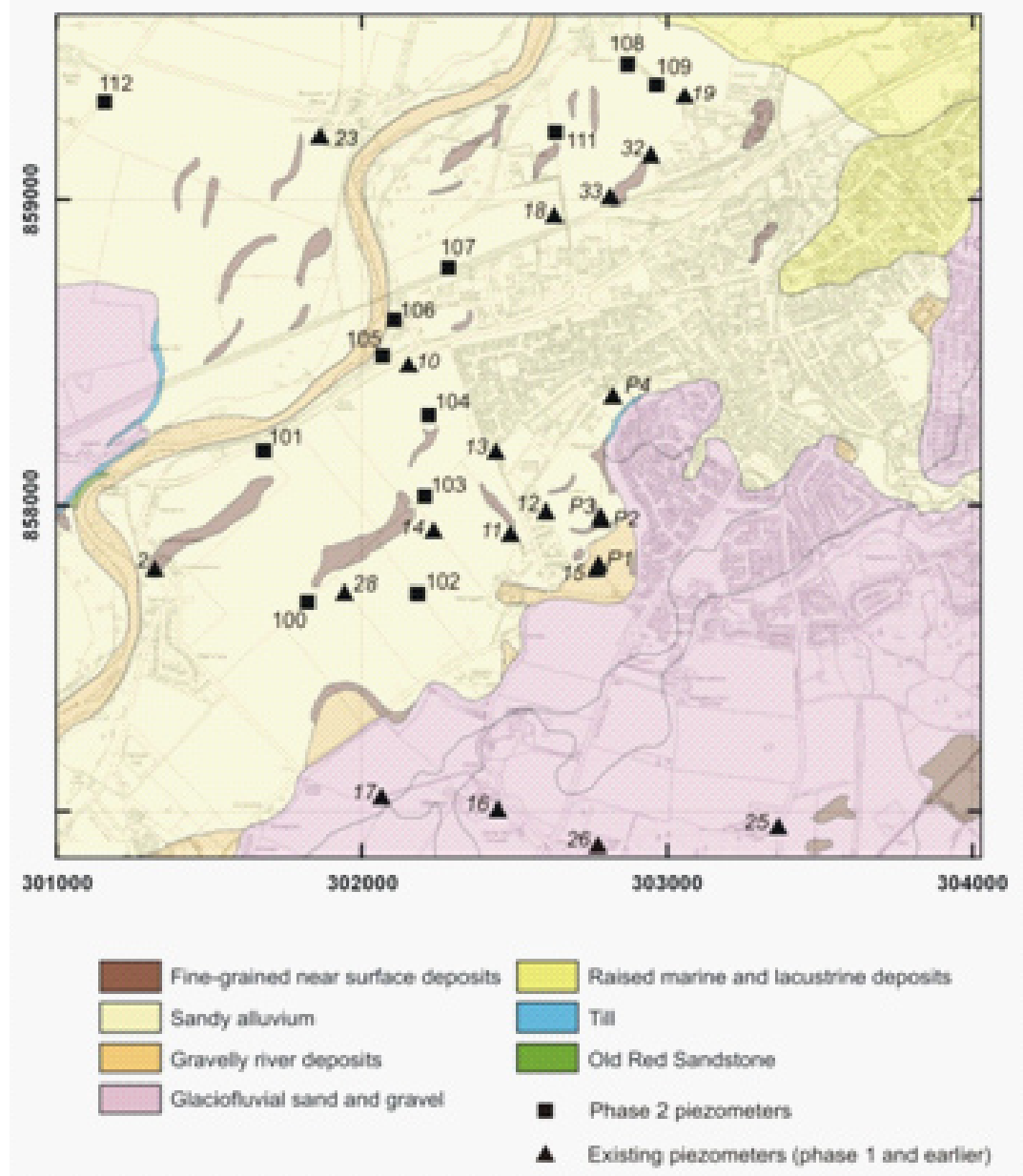

Figure 2 Geology of western Forres and the location of piezometers. 
of Forres in greater detail and with greater confidence. The results of the investigations are summarised here.

\section{Geology}

A refined Quaternary (superficial) geological map and interpreted cross-sections have been produced for the Forres based on a rapid geological field survey, interpretation of geomorphology from aerial photographs and digital surface models, derived from NEXTMap (C Intermap Technologies) and LIDAR data; interpretation of engineer's logs from 30 boreholes and more than 50 trials pits, as well as interrogation of pre-existing corporate data sets held by BGS. The new map and cross-sections indicate that a complex sequence of Quaternary deposits exists in the lower Findhorn catchment, resulting from past glacier oscillations, relative sea-level fluctuations and river down cutting. The sequence is generally more than $10 \mathrm{~m}$ thick. Twenty-six different units have been identified. These can be broadly grouped into raised marine deposits, glacial till, peat, glaciofluvial sands and gravels, gravelly river deposits, sandy alluvium and finer grained overbank deposits. The highly permeable sands and gravels occur widely throughout the floodplain whilst beds of less permeable material occur beneath, within and occasionally on top of these sands and gravels. The raised marine deposits are silty, more common at depth, and thick and extensive to the north of Forres towards the sea. A thin layer of $(<0.5 \mathrm{~m})$ of loamy soil covers much of the floodplain, and glacial till commonly covers the underlying sandstone and conglomerate bedrock, which is Devonian in age.

\section{Hydrogeology}

Aquifer properties There is a dual aquifer system in the Findhorn floodplain catchment, with a shallow superficial aquifer that is generally highly permeable, and a deeper bedrock aquifer which is less permeable. The two aquifers are not strongly connected. Within the bedrock aquifer groundwater flow is primarily through fractures and residence time of groundwater may be greater than 25 years. Transmissivity $(\mathrm{T})$ is approximately $50 \mathrm{~m}^{2} \mathrm{~d}^{-1}$.

The pumping tests indicate high variability in permeability in the superficial deposits across the floodplain (MacDonald et al., 2012). Measured transmissivity (permeability integrated over depth) varies by over three orders of magnitude, from less than $1 \mathrm{~m}^{2} \mathrm{~d}^{-1}$ to $>3000 \mathrm{~m}^{2} \mathrm{~d}^{-1}$. A complex pattern of measured transmissivity values emerges. There is a general decrease in $\mathrm{T}$ with depth (transmissivity is generally low below $8 \mathrm{~m}$ ); however, there is some variability in the shallow data with some piezometers in the depth range 6-7 m having low transmissivity (Figure 3 ). This variability is interpreted as resulting from lateral inhomogeneity in the superficial geology and is also possibly due to the presence of abandoned silt-filled river channels (see Figure 3). However the overall pattern is clear: transmissivity is generally high at shallow depths ( $<8 \mathrm{~m}$ below ground level) and in excess of

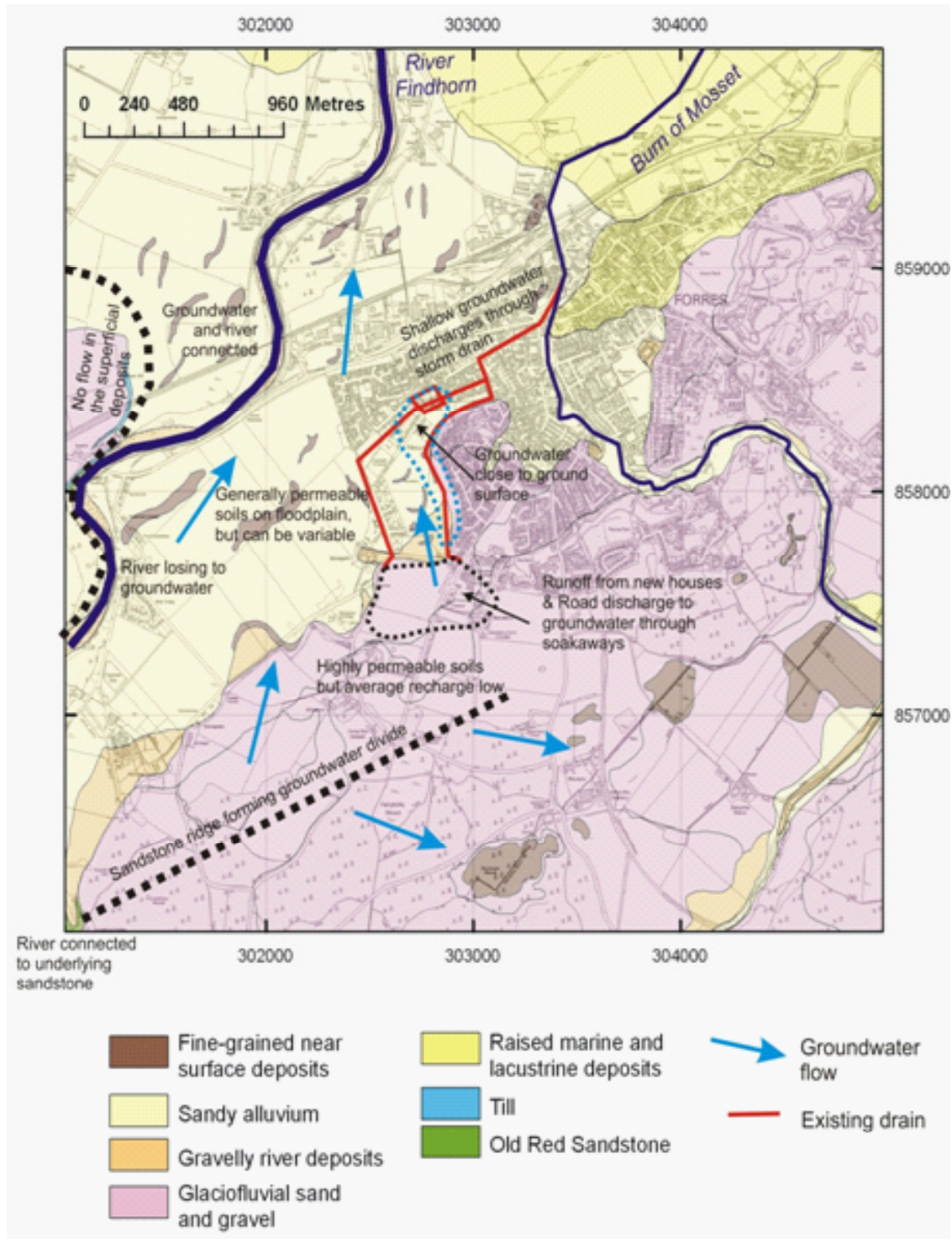

Figure 3 A summary of the main hydrogeological features of the Findhorn flood plain. 
$1000 \mathrm{~m}^{2} \mathrm{~d}^{-1}$. Given the thickness of the gravel sequences, this can be interpreted as the permeability of the shallow deposits generally being in the range of $100-1000 \mathrm{~m} \mathrm{~d}^{-1}$. The deeper (> $8 \mathrm{~m}$ ) deposits tend to have transmissivity less than $10 \mathrm{~m}^{2} \mathrm{~d}^{-1}$, although transmissivity can be higher within deeper buried channels containing more permeable material.

Groundwater flow Groundwater chemistry and water-level variations in the shallow Quaternary deposits are variable, depending on the origin of the recharging water. These data have helped provide a conceptual model of groundwater flow in the superficial deposits (Figure 3).

Groundwater flow is generally from south to north and discharges to the lower reaches of the river, drains and channels, and to Findhorn Bay. Flow is mostly within the top $8 \mathrm{~m}$ of the superficial deposits; at depth, flow is more sluggish due to the lower permeability. Groundwater residence times are less than 10-15 years in the superficial deposits. Groundwater is recharged from various sources: the River Findhorn, recharge in the upper parts of the local catchment (e.g. in the sands and gravels to the south-west of Forres) and direct recharge from rainfall on the floodplain; the River Findhorn is well connected to the aquifer system. In the south of the area, the river is losing water to the superficial deposits (and may possibly lose water to the bedrock aquifer). Further north, water-levels in the aquifer and river are similar and there is a complex interaction between river and aquifer depending on river stage. Sampling from drains indicates that groundwater discharges constantly through the existing storm drain system in Plimuir (the south-western portion of Forres), and in channels to the north of Forres. In some areas, groundwater levels are shallow and they approach ground surface in parts of Plimuir (see Figure 3).

The groundwater chemistry in the deeper bedrock aquifer is distinctive, with lower SEC values, reducing conditions and longer residence times ( $>25$ years). There is likely to be mixing between the bedrock groundwater and that from the lower portions of the superficial aquifer, but the volumes involved are unlikely to be high due to the low permeability of the deeper superficial deposits.

From the groundwater investigations it is possible to infer mechanisms for flooding in the Pilmuir area. Very shallow groundwater gives rise to marshy ground, some peat development and willow growth in parts of the floodplain. The water-logged soils also reduce the ability of rain to infiltrate. The existing storm drain continually discharges groundwater at a rate of $20-301 \mathrm{~s}^{-1}$, which reduces the capacity of the drain to take runoff. To the north of Forres it is likely that groundwater naturally floods, and that area is only kept dry by the presence of pre-existing drains and ditches. Increased urbanisation in the upper part of the catchment is likely to have increased runoff, and the use of soakaways has raised groundwater levels slightly in the lower part of the catchment.

\section{Numerical groundwater modelling}

Model construction The groundwater modelling work used the ZOOM suite of numerical groundwater models. The suite consists of a saturated groundwater flow model ZOOMQ3D, particle tracking model ZOOPT and recharge model, ZOODRM. These models have been used for a number of studies which have been reported in the literature. ZOOMQ3D has been used to investigate the impact of Climate Change on groundwater systems in the UK (Jackson et al., 2011), Spain (Guardiola-Albert and Jackson, 2011) and China (O Dochartaigh et al., 2010). The particle tracking model has been applied to examining the transport of pesticides in the Permo-Triassic sandstone in the UK (Stuart et al., 2006). ZOODRM has been applied to calculating recharge to the aquifers underlying the West Bank (Hughes et al., 2008), in northern China (O Dochartaigh et al., 2010), Marlborough and Berkshire Downs (Jackson et al., 2011) and to sub-catchments within the River Thames (Mansour et al., 2011).

The model was run initially as a steady state simulation. A dynamic balance approach was used for all prediction runs, to give a better understanding of how the system responds to seasonal variations. A dynamic balance is a model run using a repeated series of monthly average recharge. The model is run until the groundwater heads and outflows in any particular month are identical from one year to the next. Seven different scenarios were modelled which explored the groundwater response under base conditions, the response to the proposed flood alleviation engineering works, a single large recharge event (60 $\mathrm{mm}$ in one day), the storage of floodwaters on the floodplain, and also 6 months of above average recharge.

The model boundaries are shown in Figure 4. There are three rivers in the model: Muckle Burn, River Findhorn and the Burn of Mosset. The model also allows leakage to Findhorn Bay. The model was constructed with two layers representing the superficial deposits and the bedrock. The recharge was calculated using the ZOODRM recharge model using daily rainfall data and additional inputs from the soakaways around the newer housing developments. The transmissivity $(\mathrm{T})$ distribution is based on the pumping test data from the site investigations. $T$ is $1000 \mathrm{~m}^{2} \mathrm{~d}^{-1}$ over much of the floodplain, and $50 \mathrm{~m}^{2} \mathrm{~d}^{-1}$ in the superficial deposits away from the flood plain, reflecting the thin saturated zone as described in MacDonald et al. (2008). The rivers are connected to the superficial aquifer, and to the bedrock aquifer where bedrock is exposed in the river bed. The existing drain in the Pilmuir area (refined area marked in Figure 4) has been included in the model. The flow in this drain has been measured on two occasions and is in the range of $20-301 \mathrm{~s}^{-1}$.

Results of base model The model was run initially as a steady state simulation. Figure 4 shows the comparison between measured heads in November 2007 and the steady state model for the refined area. There is good agreement over much of the area of interest (8-12 m head contours), although heads are slightly too high to the north of the area of interest towards Findhorn Bay. This is likely to be due to drains not being adequately recorded in this northern area (see below). A dynamic balance approach was used for all prediction runs to give a better understanding of how the system responds to seasonal variations.

A summary of the main outcomes from the modelling on general groundwater responses in the area are as follows:

- The observed shallow groundwater levels ( $<1 \mathrm{~m}$ deep) and flow in the existing storms drains under base conditions observed in the floodplain are well represented by the model.

- The model also indicates that shallow groundwater conditions can exist all year round, and are related to rainfall events, rather than a more predictable winter high. This matches the observations from piezometers.

- The model predicts shallow groundwater-levels and in some cases groundwater flooding to the north of Forres under base conditions. This indicates the important role of the existing Victorian network of drains and open ditches in this area (not included in the model) in discharging shallow groundwater and lowering groundwater levels.

- Heavy rainfall events raise groundwater levels across the 

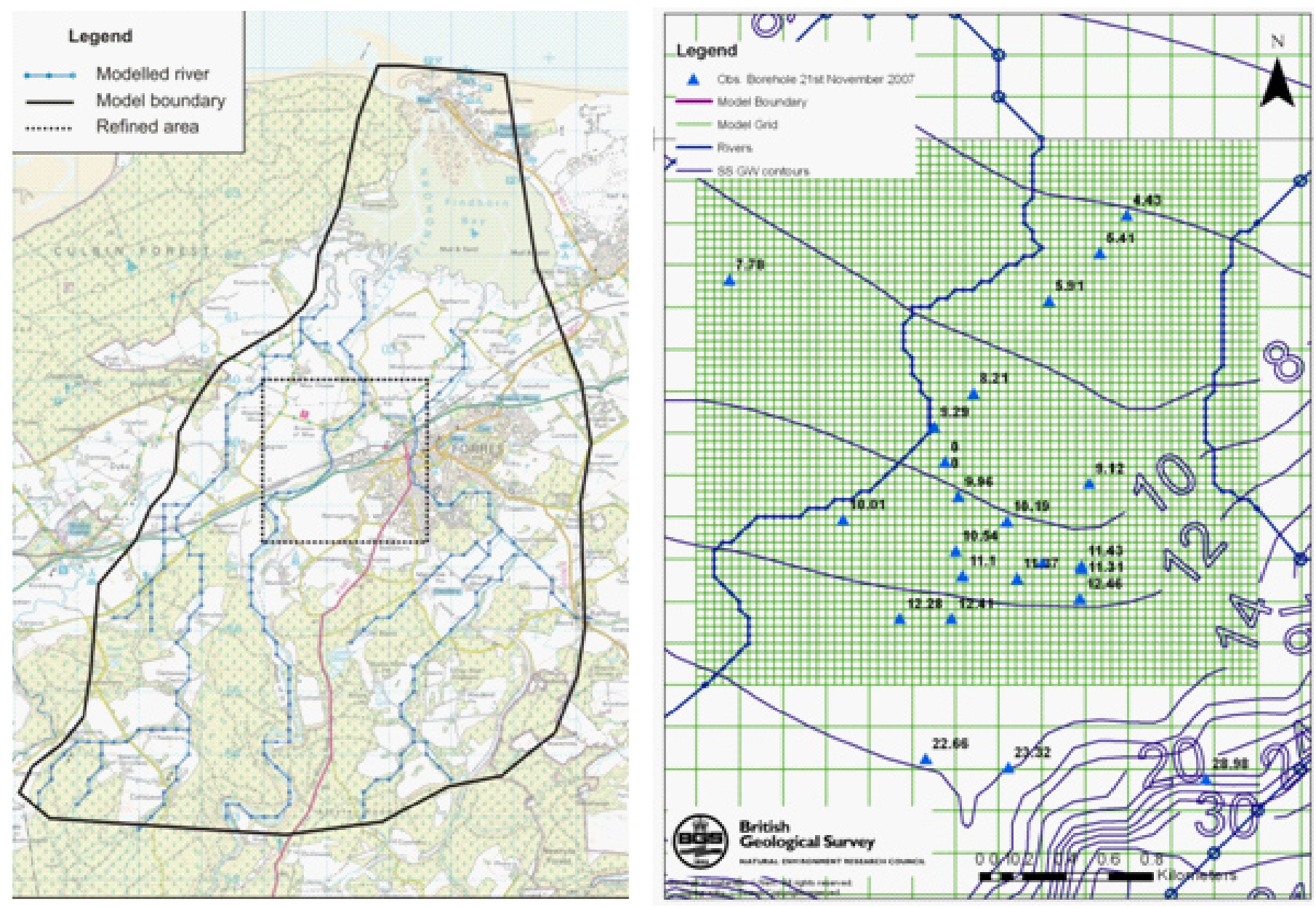

Figure 4 The outline of the modelled area, and refined model area (left). Steady-state head contours for the best steady state model compared to the observed data from 21 Nov 2007 (right). Contains Ordnance Survey Data (C) Crown Copyright and Database rights 2012. Licence No. 100021290.

entire area and considerably increase the extent of shallow groundwater levels and potential groundwater flooding.

- The existing stormwater drains in the built up area of Pilmuir have the effect of reducing groundwater-level variations in that area. However, this depends critically on the capacity of these drains, and it reduces their capacity to remove storm runoff.

Prediction runs Prediction scenarios were modelled to give an understanding of the behaviour of flood alleviation works on groundwater flooding in the Findhorn floodplain. The engineering works will allow surface water to impound on the floodplain for several days to stop the flood waters flowing through Forres. Additional drains would also be put in place to help drain groundwater after the impounded water has dissipated. The prediction runs were undertaken using a dynamic balance approach, as described above. During the flood predictions the river stage in the River Findhorn is raised, and the inundated area is represented as a series of additional recharge and river nodes. For some of the scenarios additional recharge was given to the entire modelled area to represent intense rainfall during the flooding. The flooding was assumed to happen in June, since future climate modelling suggests that the highest risk of flooding will occur during intense summer storms.

The main prediction run discussed here is a simulation of a 1-in-200 year flood from the River Findhorn accompanied by $60 \mathrm{~mm}$ of recharge across the local catchment. A 1-in-50 year flood inundation was also modelled.

The effect of impounding the floodwaters behind the embankments for 1 day allows flood water to enter the groundwater system and raise groundwater levels beneath the impounded area. For a 1-in-50 year event, the amount of water may be in the order of $100000 \mathrm{~m}^{3}$, and for a 1-in200 year event $200000-300000 \mathrm{~m}^{3}$. This is less than what would be expected if there were no engineering works and the flood waters were allowed to spread over a larger area without constraint. This additional water enters groundwater storage and discharges over the next few months back to the River Findhorn and the proposed channels constructed as part of the engineering works (Figure 6). The area of significant rise in groundwater levels $(>0.5 \mathrm{~m})$ is largely constrained to near the river. Groundwater levels will rise abruptly (up to $1.5 \mathrm{~m}$ ) and decay to near normal levels after 60-90 days. The areas that suffer from regular groundwater flooding (e.g. north Forres and the Pilmuir area, Figure 5) would be unlikely to be significantly affected by the scheme. What is noticeable about the impacts of the impounded waters on the groundwater heads is the dissipation of the groundwater mound which develops initially under the impoundment. The high heads immediately under the area of inundation recess after day 1, but the spatial extent of the impact increases with time. This can be seen by following the progress of the area of $0.1-0.25 \mathrm{~m}$ rise in groundwater heads.

The worst impact on groundwater flooding in the area is a high rainfall event (recharge of $60 \mathrm{~mm}$ in one day) coupled with exceptionally high groundwater levels in the preceding 6 months. This causes the existing drains to be overwhelmed, and more sustained groundwater flooding to occur. This is a result of the high local groundwater recharge across the area rather than the short recharge event. 


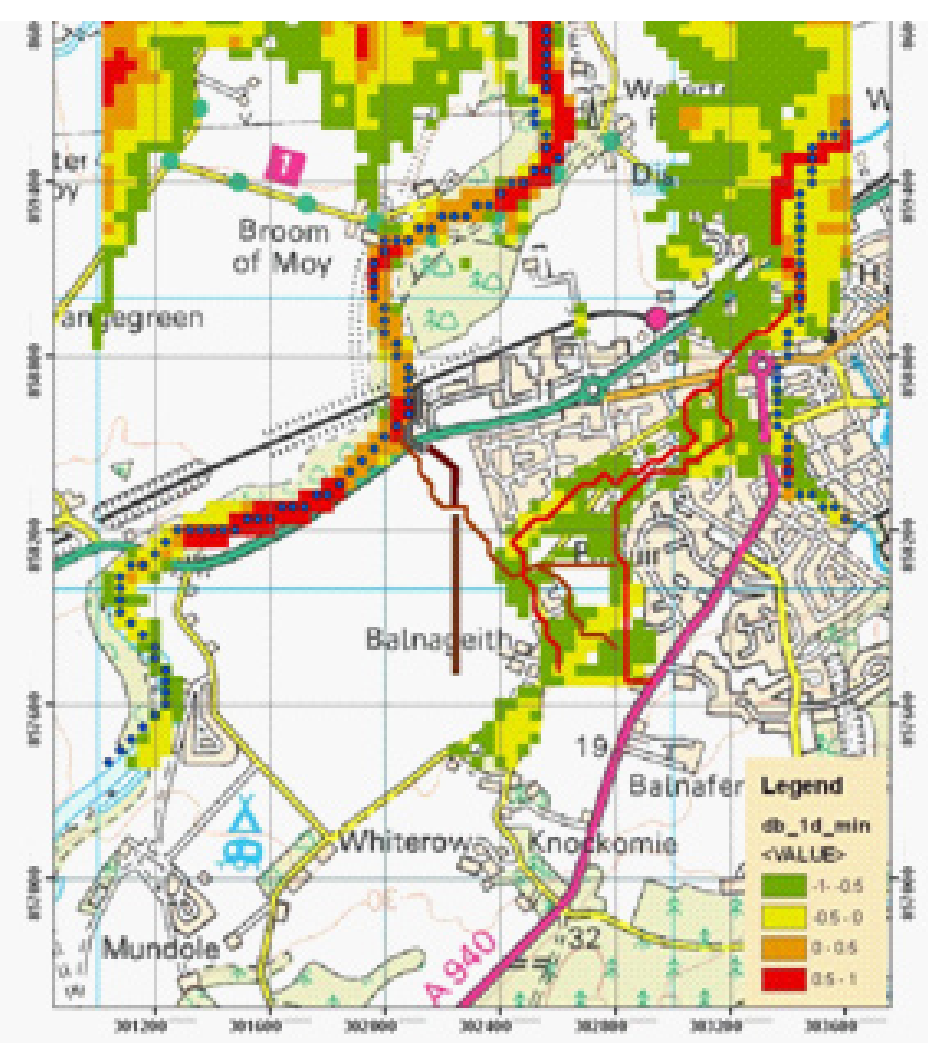

Figure 5 Modelled groundwater levels for the base run showing area where groundwater flooding is likely. Contains Ordnance Survey Data

(C) Crown Copyright and Database rights 2012. Licence No. 100021290

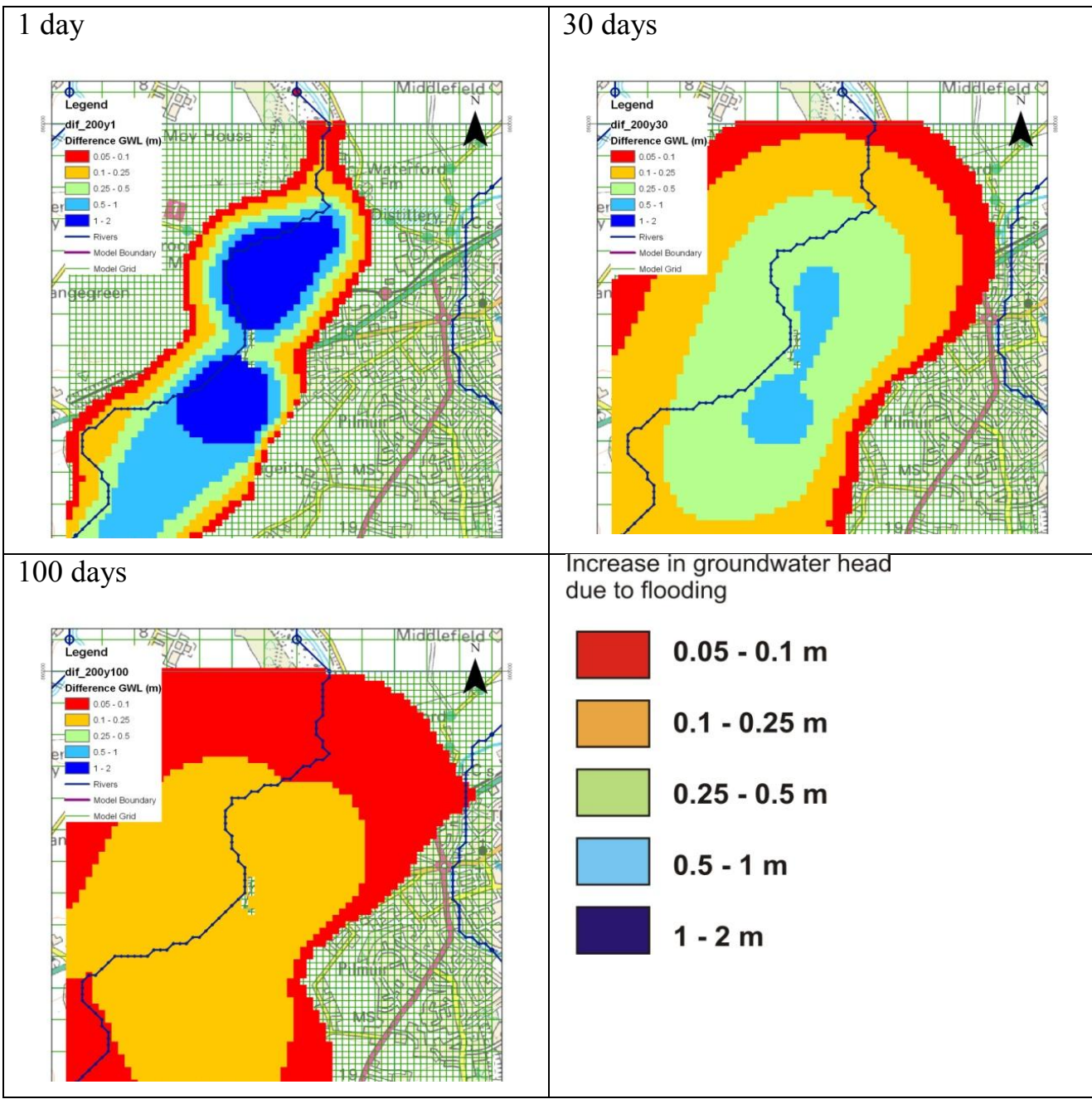

Figure 6 The difference between groundwater levels for a lin 200 year flooding event (with an embankment protecting Forres) and the basecase. Contains Ordnance Survey Data $(C)$ Crown Copyright and Database rights 2012. Licence No. 100021290 


\section{Conclusions}

The detailed hydrogeological investigations in the River Findhorn floodplain have demonstrated the important role that the Quaternary geology plays in controlling groundwater and flooding in the area.

The shallow superficial aquifer comprises Quaternary deposits dominated by sands and gravel. Transmissivity is generally high at shallow depths $(<8 \mathrm{~m})$ and in excess of $1000 \mathrm{~m}^{2} \mathrm{~d}^{-1}$. The deeper $(>8 \mathrm{~m})$ deposits tend to have transmissivity less than $10 \mathrm{~m}^{2} \mathrm{~d}^{-1}$ due to the presence of raised marine deposits and glacial tills. There is significant groundwater flow within the shallow superficial deposits. Groundwater flow is generally from south to north and discharges to the lower reaches of the rivers and Findhorn Bay.

Groundwater is recharged from various sources: the River Findhorn, recharge in the upper parts of the Pilmuir catchment and direct recharge from rainfall on the floodplain. Groundwater residence times are less than 10-15 years in the superficial deposits.

The River Findhorn is well connected to the aquifer system. In the south of the area, the river is losing water to the superficial deposits (and may possibly lose water to the bedrock aquifer). Further north, water-levels in the aquifer and river are similar and there is a complex interaction between river and aquifer depending on river stage.

This hydrogeological system gives rise to groundwater flooding, which is generally manifested by marshy areas, long periods of flooding, peat development and the evolution of a drainage network which is perennially flowing with groundwater.

A groundwater model was constructed for the area using ZOOM. This successfully represented the observations in the area and was used to undertake some predictive runs of potential impact on groundwater flooding of engineering works to control surface water flooding. The modelling indicates that the area of significant groundwater levels rise $(>0.5 \mathrm{~m})$ is largely constrained to near the river. The urban areas that suffer from regular groundwater flooding are unlikely to be significantly impacted by the scheme. The worst impact on groundwater flooding in the area is a large rainfall event (recharge of $60 \mathrm{~mm}$ in one day) coupled with exceptionally high groundwater levels in the preceding six months.

\section{Acknowledgements}

This paper is published with the permission of the Executive Director, British Geological Survey (NERC). The study was funded by Moray Council and the authors thank staff at Royal Haskonings and Moray Flood Alleviation for their assistance.

\section{References}

Choudhury, A. and Patterson, B. 2006. Pilmuir flood alleviation scheme: baseline hydraulic modelling and flood damages report. Final Draft Report for Pilmuir Drainage Flood Alleviation Scheme.

Guardiola-Albert, C. and Jackson, C.R. 2011. Potential impacts of climate change on groundwater supplies to the Doñana wetland, Spain. Wetlands, 31, 907-920.

Hughes, A.G., Mansour, M.M. and Robins, N.S. 2008. Evaluation of distributed recharge in an upland semi-arid karst system: the West Bank Mountain Aquifer, Middle East. Hydrogeol. J., 16, 845-854.

Jackson, C.R., Meister, R. and Prudhomme, C. 2011. Modelling the effects of climate change and its uncertainty on UK Chalk groundwater resources from an ensemble of global climate model projections. J. Hydrol., 399, 12-28.

MacDonald, A.M. Maurice, L. Dobbs, M.R. Reeves, H.J. and Auton, C.A. 2012. Relating in situ hydraulic conductivity, particle size and relative density of superficial deposits in a heterogeneous catchment. J. Hydrol., 434-435., 130-141.

MacDonald, A.M. 2011. The impact on the Chapelton Spring of the Burn of Mosset flood alleviation scheme. British Geological Survey Commissioned Report, CR/11/129. 23pp.

MacDonald, A.M., Hughes, A.G., Vounaki, T., Graham, M.T., Lilly, A., Mansour, M. and Stephens, C.A. 2008. Groundwater and the Forres (River Findhorn \& Pilmuir) flood alleviation acheme, Morayshire. British Geological Survey Commissioned Report, CR/08/023. 94 pp.

MacDonald, A.M., Ó Dochartaigh, B.É., Hughes, A.G., Auton, C.A., Graham, M. and Darling, W.G. 2006. Chapelton flood storage reservoir, Morayshire: potential impacts on local groundwater. British Geological Survey Commissioned Report, CR/06/130C. 62pp.

Mansour, M.M., Barkwith, A. and Hughes, A.G. 2011. A simple overland flow calculation method for distributed groundwater recharge models. Hydrol. Process., 25 , 3462-3471.

McEwen, L.J. and Werritty, A. 2007. The Muckle Spate of 1829: the physical and societal impact of a catastrophic flood on the River Findhorn, Scottish Highlands. Trans. Inst. Br. Geogr. 32, 66-89.

Ó Dochartaigh, B.E., MacDonald, A.M., Darling, W.G., Hughes, A.G., Li, J. X. and Shi, L.A. 2010. Determining groundwater degradation from irrigation in desert-marginal Northern China. Hydrogeol. J., 18, 1939-1952.

Stuart, M., Gooddy, D., Hughes, A.G. and Jackson, C.R. 2006 A field and modeling study to determine pesticide occurrence in a public water supply in Northern England. Ground Water Monit. \& Remed., 26, 128-136. 